\title{
Increasing Oxytocin Hormone Levels in Postpartum Mothers Receiving Oketani Massage and Pressure in The GB-21 Acupressure Point
}

\author{
Machmudah $^{1}$, Nikmatul Khayati ${ }^{2}$, Sri Widodo ${ }^{3}$, Elsi Dwi Hapsari ${ }^{4}$, Fitri Haryanti ${ }^{5}$ \\ 1,2,.3 Faculty of Nursing and Health Sciences, Universitas Muhammadiyah, Semarang, Indonesia. \\ ${ }^{4,5}$ School of Nursing Science, Faculty of Medicine, Universitas Gadjah Mada, Indonesia. \\ ${ }^{*}$ Correspondence E-mail : machmudah@unimus.ac.id
}

\begin{abstract}
Introduction: Breastfeeding is a physiological task for postpartum mothers. At the postpartum the condition of the body, especially the breast and hormonal system are prepared to support the lactation process. Not all mothers however can carry out this new task smoothly. Many complaints experienced by the mothers at the beginning of the lactation process including breast milk not coming out, breast milk in small amount, nipple blisters and so on. One of the factors that influences milk production is hormonal factors, namely prolactin and oxytocin. Breast care will stimulate the breast and affect hypopise to release more progesterone, estrogen and oxytocin hormones. The oxytocinhormone will cause contractions in other cells around the alveoli so that milk flows down towards the nipples.
\end{abstract}

Methodology: This type of research is a quasi-experiment using the pre post test design with control group.

Results: The study showed that there was an increase in the mean value of oxytocin hormone in the mothers after receiving the Oketani massage intervention and pressure on the jianjing GB-21 acupressure point.

Discussion: Massage can help reducing daily stress, improve the immune system and generally make people feel healthier and more relaxed. Massage has been shown to facilitate increased release of natural oxytocin. Acupressure technique at Jianjing point GB-21 is a point to stimulate let down reflexes which can stimulate lactogen hormone secretion and can increase blood circulation in the breast (Betts, 2003). Relaxation conditions experienced by the mother will increase comfort so that it increases the let down reflex and increases levels of the prolactin and oxytocin hormones (Rahayu, et al., 2015).

Keywords: Oxytocin, Oketani Massage, Postpartum Mothers, Acupressure.

\section{Introduction}

Breastfeeding is the best way to meet nutritional needs for baby's growth and development. Breast milk has high contribution in cognitive, sensory, motoric development and provides protection against infections and chronic diseases. Breast milk production is influenced by hormonal factors (prolactin and oxytocin), food intake, maternal psychological conditions, breast care, frequency of baby suckling, and consumption of drugs / hormonal contraception (Kompas, 2013). Breast care will stimulate the breast and affect hypophyse to 
release much more amount of the progesterone, estrogen and oxytocin hormones. The oxytocin hormone will cause contractions in other cells around the alveoli so that milk flows down towards the nipples.

The oxytocin hormone is located in the hypothalamus in the brain. The hormone is released by the pituitary gland located at the base of the brain. In the chemical field, oxytocin is classified as a peptide containing 9 amino acids. While according to biological classification, oxytocin is a neuropeptide, acting as a hormone and organic compounds that send signals in the brain. The oxytocin hormone is also called a love hormone because of its roles in various human behaviors, such as orgasm, social closeness, and maternal attitudes. The effects of oxytocin on behavior and emotional response are also seen in building calmness, trust and stability in psychology. Oxytocin can improve the quality of a loving relationship including wisdom, strength and wellness (Anggorowati, et al., 2018).

One way to induce the oxytocin hormone is by massage or by acupressure. The results of research on the effects of massage or stimulation on oxytocin release were explained by Morhenn, et al., 2012 that massage and skin contact with the skin and pressure on the back will increase by $17 \%$ of oxytocin production. Increased oxytocin production will affect behavior. Morhenn explained that massage will improve social behavior such as trust, kindness and empathy.

Anggorowati, 2016 explained that the use of Digital Massager Oxytocyn (DMO) affects the increase in comfort and volume of breast milk.

Breast milk that has been produced by alveoli cells due to the function of the prolactin hormone requires the oxytocin hormone to drain it. Oxytocin is influenced by the psychological condition of the mother. If the mother feels calm, comfortable, and happy, hormones will be abundant and breast milk will flow smoothly. Stimulation of baby suction during breastfeeding will continue to the hypothalamus which produces the oxytocin hormone. Furthermore, oxytocin will spur myoepithelium around the alveoli to contract and release breast milk.
This process is called letdown reflect or breast milk drainage reflex.

\section{Methods}

The research phase begins with the preparation of the proposal then proceed with the submission of a research permit. The preliminary study was carried out at Sleman District Health Center which will be used as a research location. Submission of research permits to Kesbanglinmas and Bapeda Sleman Regency then continued with permission to the $\mathrm{DHO}$ and Public Health Center Mlati II. Identification of respondents who will be used as intervention groups and control groups was conducted. The intervention group was divided into three groups, namely the group that received Oketani massage, pressure at GB21 acupressure point, and a combination of Oketani massage and pressure at GB-21 acupressure point. Then an oxytocin level was assessed on the first day (before intervention) and on the ninth day.

This type of research is quasi-experiment using pre-post test design with control group, in which a measurement is only done during the first and last day of research (Sugiyono, 2001).

Univariate analysiswas applied to describe the characteristics of respondents and dependent variables using frequency distribution. Bivariate analysis was applied to analyze differences in prolactin hormone levels in the intervention and control groups. The test used is the independent sample $T$ test.

\section{Results}

Table 1: Distribution of respondents based on age and parityin the Community Health Center Mlati II, Sleman Regency July - September 2017

\begin{tabular}{llllll}
\hline Variables & Group & Min & Max & Mean & S.D \\
\hline Age & GB-21 & 24 & 40 & 30 & 6.058 \\
& Oketani & 20 & 38 & 32 & 7.162 \\
& Combination & 24 & 42 & 32 & 7.106 \\
Parity & Control & 26 & 42 & 32 & 6.181 \\
& GB-21 & 1 & 6 & 3 & 1.92 \\
& Oketani & 1 & 3 & 2 & 0.836 \\
& Combination & 2 & 3 & 2 & 0.54 \\
& Control & 1 & 3 & 2 & 0.707 \\
\hline
\end{tabular}


From the table above it can be explained that the youngest age of respondents is 20 years in the Oketani group, the oldest age is 42 years in the combination group (Oketani and acupressure stimulation at GB-21 point). The majority of respondents parity is 3 in all groups.

Table 2. The level of the oxytocin hormone in respondents at the Community Health Center Mlati II, Sleman Regency 2017

\begin{tabular}{lllllllll}
\hline & \multicolumn{2}{l}{ Prior (Day1) } & \multicolumn{7}{l}{ After(Day 9) } \\
Group & Min & Max & Mean & SD & Min & Max & Mean & SD \\
\hline GB-21 & 0.134 & 0.169 & 0.153 & 0.029 & 0.14 & 0.193 & 0.165 & 0.021 \\
Oketani & 0.152 & 0.196 & 0.155 & 0.017 & 0.120 & 0.212 & 0.168 & 0.98 \\
Combination & 0.149 & 0.173 & 0.162 & 0.010 & 0.138 & 0.193 & 0.174 & 0.036 \\
Control & 0.111 & 0.164 & 0.144 & 0.036 & 0.114 & 0.169 & 0.147 & 0.021 \\
\hline
\end{tabular}

From table 2 above it can be explained that there was an increase in the mean level of oxytocin hormone in the respondents who were given an Oketani massage intervention of 0.168 on the ninth day. In the respondents who were given pressure intervention at Jianjing GB-21 acupressure point, the mean level of oxytocin hormone was 0.168 on the ninth day. The highest increase in the average oxytocin hormone level occurred in the group given intervention in combination between Oketani massage and pressure at GB-21 acupressure point was 0.174 . While the lowest level of oxytocin hormone levels was found in the control group (not given any intervention), which was 0.147 .

\section{Discussion}

The results above show that in the group intervened with a combination between Oketani massage and pressure at GB-21 acupressure point the oxytocin hormone levels increased by $0.174 \mathrm{on}$ the ninth day. The lowest increase occurred in the group of respondents who were not given any intervention (0.147).

Linda (2010) explains that massage is effective in helping reduce daily stress, enhancing the immune system and generally making people feel healthier and more relaxed. Massage has been shown to facilitate increased release of natural prolactin and oxytocin. According to Dr. Kerstin Uvnas Moberg, author of The Oxytocin Factor, massage is one of the best ways to get oxytocin released into the body.
Morhenn, et al., 2012 says that massage and skin contact with the skin and pressure on the back will increase oxytocin production by $17 \%$.

Massage will provide a sense of comfort and relaxation, a condition needed by mothers who are breastfeeding. Massage on breastfeeding mothers is growing a lot today and is supported by research data. One of the breast massages is Oketani massage. This massage was developed by Sotomi Oketani from Japan. Oketani massage can provide comfort and relieve pain in postpartum mothers. The postpartum mother's body becomes more relaxed. Oketani massage will make the breast softer, make the areola and the nipples more elastic, so as to make it easier for the baby to suckle. Milk flow becomes smoother because there is an emphasis on the alveoli. The techniques of Oketani massage have eight steps, seven of them are on the retromammary section and one of them is on the right and left side of the breast (the areola area containing myoepithelial). This oketane massage is carried out for 15-20 minutes (Kabir, 2009).

The results of the above research are in line with the theory of Foda (2004), explaining that Oketani massage can increase the production of the prolactin and oxytocinhormone. Prolactin is responsible for the production of breast milk in the alveoli, while the oxytocin hormone can stimulate the mammary gland to secrete breast milk.

Anggorowati (2016) explained that the use of Digital Massager Oxytocyn (DMO) affects the 
increase in comfort and volume of breast milk. Oxytocin produced during the breastfeeding process has been studied to have a relaxing effect which causes breastfeeding mothers to feel calm and even have euphoric effects, so that higher levels of oxytocin can prevent the occurrence of postpartum blues (Riordan \& Auerbach, 2010 in Rahayu et al., 2015).

Wulandari, 2015 in her research explained that there was an effect of oxytocin stimulation massage on Let Down Reflex (LDR) in post partum mothers in RB Mardi Rahayu Kalibanteng, Semarang.

Another way to stimulate lactogen hormone secretion besides massage is to put pressure (stimulation) on the acupressure point Jianjing GB-21 (Gall Bladder 21). The results showed that in the group of respondents who were given pressure intervention at Jianjing GB-21 acupressure point (Gall Bladder 21) there was an increase in the mean oxytocin level of 0.165 on the ninth day (on the first day the average oxytocin hormone level was 1.53).

The jianjing GB-21 acupressure point can be used to increase let down reflex. Pressure at this point can also be given when the mother experiences muscle tension and can be a fun way for the mother to feel calm and relax during breastfeeding (Betts, 2003).

Pressure on the Jianjing GB-21 acupressure point is one part of the technique of acupressure points for lactation with the traditional Chinese medicine approach. Aacupressure points for lactation technique is one solution to overcome the inefficiency of breast milk production (Anamed, 2012 in Rahayu, 2015). This technique can help maximize prolactin and oxytocin receptors and minimize the side effects of delays in breastfeeding by the baby (Evariny, 2008 in Rahayu, 2015). Acupressure points for lactation can also increase the feeling of relaxation in postpartum mothers. Acupressure points for lactation through meridians according to the intended organ can help reduce discomfort that can suppress lactogen hormone production. Acupressure will increase levels of endorphins in the blood and systemic. Acupressure stimulation can bring the substance to the release of substances that can inhibit pain signals to the brain. The effect of acupressure stimulation can pass through the nerve and can be through hormonal transmitters that has not been able to be explained clearly (Garret et al., 2003 in Apriany, 2010: Saputra 2000).

This is supported by the theory of gate control which explains that stimulation at an acupressure point on a meridian pathway will be forwarded by large diameter A-Beta nerve fibers to the spinal nerve which then in the spinal cord there is a gelatinosa substance acting as a gate control before being forwarded by afferent nerve fibers towards the transmission cells, which then channel to the central nervous system by reducing discomfort (Hakam, Krisna \& Tutik, 2009 in Rahayu et al., 2015).

Massage performed in acupressure points will eliminate tension and can cause relaxation of body muscles (Gach, 1990; Hongzhu, 2002 in Rahayu et al., 2015). The conditions will cause a sense of comfort that will have a positive impact on feeling calm, comfortable, relaxed and decreased stress. Gach, 1990 in Rahayu et al, 2015 explained that acupressure massage will stimulate an increase in the body's natural morphin, i.e., endorphin. A comfortable, calm and relaxed atmosphere will bring positive emotions that can increase the secretion of endorphin neurotransmitters through POMC which serves as a pain reliever and excessive control of CRF secretion (Sholeh, 2006). A decrease in CRF will be followed by a decrease in ACTH and the adrenal medulla will respond by decreasing catecholamine secretion, then peripheral resistance and cardiac output will decrease so that blood pressure decreases (Putra, 2005 in Rahayu, et al 2015). Relaxation conditions experienced by the mother will increase comfort so that it increases the let down reflex and increases levels of the prolactin and oxytocin hormone (Rahayu, et al, 2015).

Morhenn, et al., 2012 explained that massage can reduce $6 \%$ stress marker hormones, namely, Adrenocorticotrophin hormone (ACTH).

Acupressure points for lactation are actions that can stimulate the production of prolactin hormones from the brain (Rahayu et al., 2015). Points that are acupoint lactations 
include ST 17 (Ruzhong), ST 18 (Rugen), and Jianjing GB-21. This massage on acupoint aims to increase the production of the prolactin and oxytocin hormone. This acupressure point can be used to increase let down reflex. Pressure at this point can also be given when the mother experiences muscle tension and can be a fun way for the mother to feel calm and relax during breastfeeding (Betts, 2003).

This is consistent with the research conducted by Rahayu et al., 2015 which states that the pressure on acupressure points for lactation can improve comfort and can also increase production and release of breast milk.

\section{Conclusions}

Oketani massage can increase the mean oxytocin hormone level by 0.168 on the ninth day. Stimulation on the acupressure point of jianjing GB-21 (Gall Bladder 21) point can

\section{References}

Afifah, D.N., (2007). Faktor yang berperan dalam Kegagalan Praktek Pemberian ASI Eksklusif. Tesis. Undip Semarang.

Anggorowati, A., Susilowati, D., Zubaidah, (2018). Effect of Engineered Stimulation of Oxytocin on Hormonal Status of Postpartum Women. Hiroshima, Journal Medicine Sciences. 67(Sp. Issue), pp.9196.

Anggorowati, A., Sutadi, H., Setyowati, Koestoer, R. A. (2016). Effect of Acupoint Stimulation with Digital Massager of Oxytocin on the Breast Milk Production of Working Mothers. Nurse Media Journal of Nursing, 6(2), 91-100.

Apriany, D. (2010). Apriany, D. 2010. Pengaruhterapi music terhadap mual muntah lambat akibat kemoterapi pada anak usia sekolah yang menderita kanker di RSUP Dr. Hasan Sadikin Bandung. Thesis: Magister Universitas Indonesia. Fakultas ILMU Keperawatan.

Betts, Debra, (2007). Acupressure; Promoting a natural labour and partner involvement. ISBN 0473-04467-6

Bobak, I.M., Lowdermilk, D.L., Jensen, M.D., Perry, S.E. (2005). Buku Ajar Keperawatan Maternitas. Edisi 4. Alih bahasa: Maria \& Peter. Jakarta: EGC.

Depkes, R.I. (2007). Pelatihan Konseling Menyusui. Jakarta: Depkes RI increase the mean oxytocin hormone level by 0.165 on the ninth day, the combination of the two interventions can increase the oxytocin hormone level by 0.174 on the ninth day.

\section{Suggestion}

Oketani massage and pressure on the Jianjing GB-21acupressure point can be used as one of the scientific study materials in the classroom learning process for Nursing students. Both of these interventions can also be used as an alternative to independent actions of nurses in supporting lactation success with a complementary nursing approach.

This study needs to be further developed by examining the effect of oxytocin on the mothers who performed massage on the immune system of the mother and baby.

Evariany, A. (2007). Agar ASI lancar diawal masa menyusui. Diunduh dari http://www.hypnobirthing.web.id/? Diunduh tanggal 10 Februari 2013.

Foda, M. I., Kawashima, T., Nakamura, S., Kobayashi, M., Oku, T. (2004). Composition of Milk Obtained from Unmassaged Versus Massaged Breasts of Lactating Mothers. Journal of Pediatric Gastroenterology and Nutrition. 38(5), pp. 484-487.

Haryani, (2014). Alasan tidak memberikan ASI Eksklusif pada lbu bekerja di Kota Mataram NTB. Tesis. Universitas Udayana Bali.

Ibu \& Balita. (2013). Memantau Pertumbuhan melalui berat badan bayi. Diunduh dari http://www.ibudanbalita.com/pojokcerdas/memanta u-pertumbuhan-melalui-berat-badan-bayi, tanggal 09 November 2013.

Jeongsug, Hye, Y., Sukhee \& Myeong Soo. (2012). Effects of Oketani Breast Massage on Breast Pain, the Breast Milk pH of Mothers and The Sucking Speed of Neonates. Journal of Korean J Women Health Nurs. 18(2), pp.149-158.

Kabir, N. \& Tasnim, S. (2009). Oketani Lactation Management : A New Method to Augment Breast Milk. Journal of Bangladesh College of Physicians and Surgeon, 27(3). doi: https://doi.org/10.3329/jbcps.v27i3.4293. 
Lowdermilk, D.L., Perry, S.E., Bobak, I.M. (2000). Maternity women's health care. $7^{\text {th }}$ ed. St. Louis: Mosby.Inc

Lowe, Lee. (2012). Acupressure Point. Diakses. Source: www.ana-med.co.nztanggal 11 Mei 2016

Machmudah \& Khayati. (2013). Produksi ASI pada ibu postpartum yang dilakukanpijatoksitosin dan oketani di Kota Semarang.

Machmudah, Khayati, Isworo. (2014). Komposisi Kimia ASI pada Ibu Postpartum yang dilakukan Pijat Oksitosin dan Oketani di Kota Semarang.

Morhenn, V., Beavin, L., E., Zak, P. J. (2012). Massage Increases Oxytocin and Reduces Adrenocorticotropin Hormone in Humans. Journal Alternative Therapies. 18(6), pp.11-18.

Pilliteri. (2003). Maternal and child Health Nursing. Care of Childbearing and Childrearing Family. $3^{\text {rd }}$ edition. Lippincott
Rahayu, D., Santoso, B. \& Yunitasari, E. (2015). The Difference In Breastmilk Production Between Acupresure Point for Lactation and Oxytocin Massage. Jurnal NERS. 10(9), pp. 9-19.

Riordan, J. \& Aurbach, K. G, (2010). Breast feeding and Human Lactation. London: Jones anbarlett Publishers International.

Roesli, U. (2005). Mengenal ASI Eksklusif. Jakarta : Trubus Agriwidya.

Roesli, U. (2009). Manajeman Laktasi. Jakarta : IDAI.

Saputra, K. (2000). Akupunktur dalam ilmu kedokteran. Surabaya : Airlangga University Press.

Sugiyono. (2001). Statistik untuk Penelitian. Bandung : CV. Alfabeta

Wong , D.L., Perry, S.E., \& Hockenberry, M.J. (2002). Maternal Child Nursing Care. $\left(2^{\text {nd }}\right.$ ed). St. Louis : Mosby. 